However, Malaya's Education Minister, Datuk Musa Hitam, is currently tightening up on the ease with which Malay students can at present enter university. In particular, he is reducing the proportion of Malay to Chinese and Indian students by 2 per cent a year until a final figure of 55 per cent bumiputra - literally "sons of the soil" - and 45 per cent non-bumiputra is achieved in the country's five universities. This is roughly equivalent to the racial balance in the country, but between 1970 and 1975, for example, the preference given to Malays increased their size as a proportion of student intake from 50 to 65 per cent.

Speaking at the opening of an educational building in Kuala Lumpur, $\mathrm{Mr}$ Datuk Musa was quoted as saying that this development should be taken as a "warning signal" to both bumiputra students and their parents that entrance to universities would in future depend less on their racial status and more on their academic achievement.

There is less political pressure to change the impact of present policies on the makeup of university staff. Part of the restructuring policy has been to increase considerably the number of Malay teachers and administrators in both schools and universities, again with the intention of redressing previous imbalances.

Chinese and Indian teachers accept both the logic of this policy and the political needs on which it is based. But in private, many express unhappiness that appointments, even at relatively senior administrative levels, are sometimes made with little respect for academic merit, and that in the process their own promotion prospects have been significantly reduced.

University staff in Malaya, however, are forbidden as government employees from taking part in any attempt to change policy. Lacking significant political power, their only options are frequently either to accept their reduced prospects or to seek teaching or research appointments abroad.

David Dickson

\section{Antarctic research}

\section{Germany joins in}

A bid for a voice in the future development of the Antarctic may be behind West Germany's massive new research programme in the area. Details published recently* show that West Germany will become second only to the United States in the size of its investment in Antarctic research.

Although West Germany acceded to the Antarctic Treaty in 1979 , it is still not admitted to the inner consultative group of countries which discuss matters beyond research, such as the exploitation of krill,

*Antarktisforschungsprogramm der Bundesrepublik Deutschland, Bundesministerium für Forschung und Technologie, Bonn. An English summary is available. one of the last great untapped food resources of the sea, and the development of possible offshore oil supplies. In the wording of the treaty, admission to the consultative group is reserved for the original 12 signatories (which did not include West Germany) and for any later signatory demonstrating its interest in Antarctica either by conducting substantial scientific research activity there - such as the establishment of a scientific station or by the despatch of a scientific expedition.

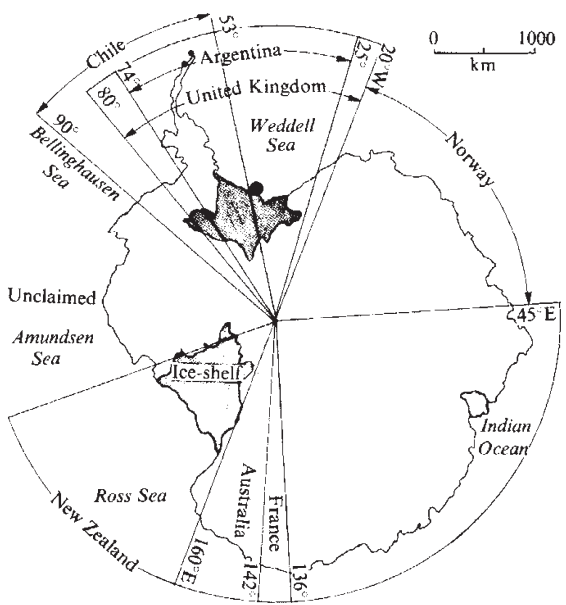

\section{Germany for blob in Weddell Sea}

West Germany is doing both. It is creating a new 20-man research and training institute at Bremerhaven to direct its Antarctic programme, building a supply and research ship and purchasing one or two Lockheed $\mathrm{C} 130$ transport aircraft (the largest planes on skis). Its commitment will cost DM 385 million ( $£ 85$ million) to the end of 1983, with a large fraction going on capital equipment and buildings.

The Bremerhaven centre will be called the "Alfred Wegener Institut für Polarforschung" after the originator of the concept of continental drift, who died on an expedition to Greenland in 1930. The institute will open in January 1981 under the directorship of Dr Gotthilf Hempel, a marine biologist now at the University of Kiel, while the research ship, which has been placed on order at a German shipyard, will be launched in 1982 .

Officials at the federal research ministry were at pains last week to demonstrate West Germany's long research interest in Antarctica. Germans were among the first explorers of the polar continent, with expeditions in 1873, 1901, 1911 and 1938. The last expedition, according to some commentators, was not research but an effort by Hitler to establish a territorial claim and was overtaken by the events of the Second World War. The region explored at that time (called New Schwabenland and Queen Maud Land) is now claimed by Norway. After the war, West Germany was too preoccupied with economic reconstruction to bother with the Antarctic. Interest revived in 1975 when a research ship was sent to investigate krill.

\section{Antarctic politics}

Antarctic politics are tortuous, a product of random historical and geographical factors and the current interest in food and oil resources. The Antarctic Treaty was set up after the International Geophysical Year of 1957-58, and ratified in 1961 by twelve nations: Argentina, Australia, Belgium, Chile, France, Japan, New Zealand, Norway, South Africa, the United Kingdom, the United States and USSR. Since then Bulgaria, Brazil, Czechoslovakia, Denmark, East Germany, West Germany, the Netherlands, Poland and Romania have acceded to the treaty, but of these only Poland has so far joined the allimportant "consultative group" (which otherwise consists of the first 12 signatories). West Germany has applied to do so and is awaiting admittance.

The treaty forbids new territorial claims on Antarctica, but has no effect on previously asserted rights or claims. Before the treaty, Argentina, Australia, Chile, France, New Zealand, Norway and the United Kingdom had claimed sectors of the continent centred on the South Pole. These states recognize each other's claims, except Chile, Argentina and the United Kingdom, which have largely overlapping claims. The claims do not affect the placing of research stations: West Germany's proposed station will be on the edge of the Ronne ice shelf, near Berkener Island in the krillrich Weddell Sea, on territory disputed between Argentina and the United Kingdom. The Antarctic Treaty confirms free access to all areas of Antarctica to all signatories. The legal status of the territorial claims, relevant only to resource development, is untested.

Surveys for an Antarctic research station began in 1979. The chosen site near Berkener Island is on the edge of the Ronne ice shelf, an extension of the Antarctic ice sheet over the shallows of the Weddell Sea. The station is now under construction and by late 1981 it will begin to serve as a scientific observatory for 45 scientists and technicians and a supply base for expeditions within a $1,000 \mathrm{~km}$ radius, wide enough to include the geologically interesting Palmer, Ellsworth, Pensacola and Shackleton mountain ranges.

Two other nations are also increasing their efforts in Antarctica - Australia and Argentina. Australia announced recently that it would completely re-equip its existing stations in Antarctica, at a cost of $£ 20$ million. Argentina is planning to construct the first all-weather, hardsurface landing strip as a potential refuelling base for commercial transpolar flights. Argentina is also constructing a new icebreaker for Antarctic work.

Robert Walgate 